Sharif University of Technology
Scientia Iranica
Transactions C: Chemistry and Chemical Engineering
w
I RANw.scientiairanica.com

Research Note

\title{
Toxic effects of chronic feeding with food azo dyes on Drosophila melanogaster Oregon $\mathrm{R}$
}

\author{
H. Uysal ${ }^{\mathrm{a}}$, S. Genç ${ }^{\mathrm{a}}$ and A. Ayar ${ }^{\mathrm{b} *}$ \\ a. Department of Biology, Faculty of Science, Atatürk University, 25240, Erzurum, Turkey. \\ b. Sabuncuoğlu Şerefeddin Health Services Vocational School, Amasya University, 05100, Amasya, Turkey. \\ Received 5 January 2017; received in revised form 24 April 2017; accepted 23 July 2017
}

\section{KEYWORDS \\ Drosophila; Food azo dyes; Longevity; \\ Larval mortality; \\ Toxic effects.}

\begin{abstract}
Artificial azo dyes are widely used as coloring agents for foodstuffs, drugs, and cosmetics. In this study, the toxic effects of four different synthetic food dyes (Ponceau 4R, Sunset Yellow, Amaranth, Tartrazine) on $72 \pm 4 \mathrm{~h}$ larvae of Oregon (R) wild type of Drosophila melanogaster were investigated. In addition, depending on chronic feeding, the life span of the flies was determined. For this purpose, six different concentrations of food dyes $\left(5,10,15,20,25\right.$, and $\left.30 \mathrm{mg} \mathrm{mL}^{-1}\right)$ were selected by preliminary studies to determine $\mathrm{LD}_{100}$ values. The effects of the food dyes on longevity were studied separately in female and male populations. It was determined that the maximum mean life span of the female and male D. melanogaster populations decreased with increasing concentrations of food dyes. Based on the results obtained from the larval mortality and life span experiments, the order of toxicity for food dyes was: Tartrazine $>$ Amaranth $>$ Sunset Yellow $\geq$ Ponceau $4 \mathrm{R}$.

(C) 2017 Sharif University of Technology. All rights reserved.
\end{abstract}

\section{Introduction}

Parallel to the growing world population, people's supply and demand are increasingly. Nowadays, it is very easy for people to have access to food, thanks to the food additives in daily shopping [1]. Color is one of the important features evaluated by food users. A wide range of food dyes are used to make food products more aesthetically appealing to consumers and restore their original appearance lost during the manufacturing process [2]. Today's food dyes are grouped into two main groups: natural and synthetic [3]. Synthetic food dyes are comprised of azo, triphenylmethane, fluorescein, and sulphonated indigo dyes. Azo dyes, as

\footnotetext{
*. Corresponding author. Tel.: +90 3582400016 ;

Fax: +9035 82400026;

E-mail address: arif.ayar@amasya.edu.tr (A. Ayar)
}

one of these subgroups, consist of a diazotized amine group containing one or more azo bonds $(\mathrm{R}-\mathrm{N}=\mathrm{N}-\mathrm{R}$ ) bonded with an amine or a phenol. These dyes are widely used in textile, food, plastic, paper, cosmetics, and pharmaceutical industries [4]; also, they constitute about $65 \%$ of the commercial paint market [5].

It is very important to investigate the adverse effects of synthetic products used so much on human beings, especially on the living things. There are many studies related to this issue in the literature. Studies conducted with various azo dyes have found that some metabolites of these dyes may produce genotoxic effects in humans and animals [6,7]. In addition, a histopathological study with rats has shown that these dyes cause toxic effects on the liver and kidney tissues [8]. Chung [9] emphasized that many azo dyes, their reduced products, and their associated aromatic amines are carcinogenic and allergenic. Epidemiological and toxicological studies on experimental animals, such as mice, rats and bacteria, however, show that azo 
stains may be genotoxic and carcinogenic under certain conditions [10-13].

Ponceau 4R, Sunset Yellow, Amaranth, and Tartrazine azo dyes are used most commonly. In this study, the effects of these four different azo dyes on larval mortality and longevity in Drosophila melanogaster were investigated at different concentrations.

\section{Materials and methods}

The flies used in the experiments were Oregon $\mathrm{R}$ wild type (w.t.) strain of Drosophila melanogaster Meigen (Diptera; Drosophilidae). This stock has been maintained for many years in the Genetics Laboratory at the Department of Biology of the Atatürk University in Erzurum and is, therefore, highly inbred with little genetic variation.

\subsection{Experiments of larval mortality}

Ten pairs of adult $D$. melanogaster $\left(10\right.$ 우 $\left.\times \sigma^{x} \sigma^{x}\right)$ were placed into culture bottles. Eggs were collected during $4 \mathrm{~h}$ periods in culture bottles containing standard medium. After $72 \mathrm{~h}$ of treatment, the larvae were washed and selected. Four food dyes were prepared at $5,10,15,20,25$, and $30 \mathrm{mg} \mathrm{mL}^{-1}$ separately. For chronic feeding, small culture vials were prepared with $1.5 \mathrm{~g}$ dry instant Drosophila medium (Carolina Biological Supply Company Burlington, NC) and $5 \mathrm{~mL}$ of the respective test solutions. A hundred larvae were placed on this medium. The larvae were fed with different concentrations of the food azo dyes. Feeding ended with pupation of the surviving larvae. The developmental stages were followed daily. The experiments were repeated three times.

\subsection{Experiments of longevity}

Longevity experiments were conducted separately on female and male populations. First of all, it is ensured that individuals are of the same age and have not matched in terms of food dyes of the single variable parameter. For this purpose, 100 individuals from the pups developed from the larvae grown in SDM (Standart Drosophila Medium) were immediately collected and separated as male-female. The individuals obtained here were transferred to culture bottles containing Amaranth, Ponceau 4R, Sunset Yellow, and Tartrazine food stains at different concentrations for applications after being fasted for 2 hours in empty culture flasks. Individuals fed acutely for 2 hours were transferred to new bottles containing SDM, 25 females and 25 males, and then observations started. All applications were carried out in thermal cabinets with suitable temperature, humidity, and $\mathrm{pH}$. Transfers were made to the freshly-grown culture bottles two days a week until the last individual, and the death rates were recorded. All applications were repeated 3 times, and the results were compared statistically with Duncan's one-way ANOVA. Differences between the control group and the treatment groups were assessed at $P<0.01$.

\section{Results}

All food dyes used in our study, in a concentrationdepended manner, increased the larval mortality and decreased the number of adult individuals in all the application groups (Table 1 (a)-(d)). However, the values of surviving and matured individuals, $96 \pm 1.15$ per the control group on larvae, which were fed only with SDM were determined in the lowest and highest concentrations (5-30 mg mL ${ }^{-1}$ ) for Ponceau 4R $35 \pm$ 2.88-86 \pm 1.15 (Table 1(a)), for Sunset Yellow $32 \pm 1.15$ $82 \pm 1.15$ (Table 1(b)), and for Amaranth $18 \pm 3.46$ $80 \pm 2.88$ (Table $1(\mathrm{c})$ ), respectively. Only the first three application groups $\left(5,10\right.$, and $\left.15 \mathrm{mg} \mathrm{mL}^{-1}\right)$ in Tartrazine, development of larvae, and adult individuals were observed. The rate of survival was identified as $52 \pm 2.31$ in the lower application group $\left(5 \mathrm{mg} \mathrm{mL}^{-1}\right.$ as this value $10 \pm 1.15$ in $15 \mathrm{mg} \mathrm{mL}^{-1}$ application group) (Table $1(\mathrm{~d})$ ). Based on (Table $1(\mathrm{a}-\mathrm{d})$ ), the results for the food dyes show a positive correlation between increasing dose and toxic effects. There was a statistically significant difference between the control and experimental groups at 0.01 level. Considering the occupancy rates of the larvae survived, the sort of food dyes toxicity was: Tartrazine $>$ Amaranth $>$ Sunset Yellow $>$ Ponceau 4R.

In the second part of our experiment, we studied the effect of food dyes on the longevity of mature individuals. Analyses were separately performed on male and female populations. In our study, we found that the maximum life span of the control group was 98 days for females and 91 days for males. In addition, these values of the female application groups were respectively as follows: 53-87 days for Ponceau 4R (Table 2(a)), 46-74 days for Sunset Yellow (Table 2(b)), and 39-74 days for Amaranth (Table 2(c)) in the lowest and highest concentrations $\left(5-30 \mathrm{mg} \mathrm{mL}^{-1}\right)$. It was found that the maximum life span of male application groups was 42-74 days for Ponceau 4R (Table 2(a)), 4277 days for Sunset Yellow (Table (2b)), and 35-67 days for Amaranth (Table 2(c)).

It was determined that the mean life span was $66.42 \pm 1.89$ days for 우 and $62.04 \pm 1.65$ days for $\sigma^{7} \sigma^{7}$ in the control group. In the female application groups, these values belonging to the lowest and highest concentrations $\left(5-30 \mathrm{mg} \mathrm{mL}^{-1}\right)$ were $58.43 \pm 1.95-28$ \pm 1.48 days for Ponceau 4R (Table 2(a)), 51.69 \pm 1.79 $24.01 \pm 1.41$ days for Sunset Yellow (Table 2(b)), and $50.41 \pm 1.97-22.50 \pm 1.17$ days for Amaranth (Table 2(c)). Moreover, it was observed that the mean life span was $42.76 \pm 1.91-21.66 \pm 1.06$ days for Ponceau 4R (Table 2(a)), $46.91 \pm 1.93-19.12 \pm 1.27$ 
Table 1. Rate of mortality of larvae fed with different concentrations of food dyes.

\begin{tabular}{|c|c|c|c|c|c|c|c|c|c|}
\hline \multicolumn{5}{|c|}{ Application } & \multicolumn{5}{|c|}{ Application } \\
\hline $\begin{array}{l}\text { Concentrations } \\
\qquad\left(\mathbf{m g ~} \mathbf{m L}^{-1}\right)\end{array}$ & $\sum_{\text {Larva }}$ & \begin{tabular}{l}
\multicolumn{2}{c}{ groups } \\
$\begin{array}{lll}1 & 2 & 3\end{array}$
\end{tabular} & $\begin{array}{l}\text { Mean } \\
\pm \text { S.E }\end{array}$ & \multirow[t]{2}{*}{$p$} & $\begin{array}{c}\text { Concentrations } \\
\left(\mathbf{m g} \mathbf{m L}^{-1}\right) \\
\end{array}$ & $\sum_{\text {Larva }}$ & groups & $\begin{array}{l}\text { Mean } \\
\pm \text { S.E }\end{array}$ & $p$ \\
\hline \multicolumn{4}{|c|}{ (a) Ponceau 4R, LD ${ }_{100}: 35 \mathrm{mg} \mathrm{mL}^{-1}$} & & \multicolumn{5}{|c|}{ (b) Sunset Yellow, LD $100: 35 \mathrm{mg} \mathrm{mL}^{-1}$} \\
\hline Control & 100 & 969498 & $96 \pm 1.15$ & & Control & 100 & 969498 & $96 \pm 1.15$ & \\
\hline 5 & 100 & 888684 & $86 \pm 1.15$ & & 5 & 100 & 848280 & $82 \pm 1.15$ & \\
\hline 10 & 100 & 807876 & $78 \pm 1.15$ & & 10 & 100 & 807570 & $75 \pm 2.88$ & \\
\hline 15 & 100 & 726864 & $68 \pm 2.31$ & $<0.01^{*}$ & 15 & 100 & 636159 & $61 \pm 1.15$ & $<0.01^{*}$ \\
\hline 20 & 100 & 605754 & $57 \pm 1.73$ & $<0.01^{*}$ & 20 & 100 & 585450 & $54 \pm 2.31$ & $<0.01^{*}$ \\
\hline 25 & 100 & 585042 & $50 \pm 4.61$ & $<0.01^{*}$ & 25 & 100 & 474339 & $43 \pm 2.31$ & $<0.01^{*}$ \\
\hline 30 & 100 & 403530 & $35 \pm 2.88$ & $<0.01^{*}$ & 30 & 100 & 343230 & $32 \pm 1.15$ & $<0.01^{*}$ \\
\hline \multicolumn{4}{|c|}{ (c) Amaranth, $\mathrm{LD}_{100}: 30 \mathrm{mg} \mathrm{mL}^{-1}$} & & \multicolumn{5}{|c|}{ (d) Tartrazine, $\mathrm{LD}_{100}: 15 \mathrm{mg} \mathrm{mL}^{-1}$} \\
\hline & & $\begin{array}{lll}1 & 2 & 3 \\
\end{array}$ & Mean \pm S.E & $p$ & & & $\begin{array}{lll}1 & 2 & 3 \\
\end{array}$ & Mean \pm S.E & $p$ \\
\hline Control & 100 & 969498 & $96 \pm 1.15$ & & Control & 100 & 969498 & $96 \pm 1.15$ & \\
\hline 5 & 100 & 858075 & $80 \pm 2.88$ & & 5 & 100 & 485256 & $52 \pm 2.31$ & $<0.01^{*}$ \\
\hline 10 & 100 & 747672 & $74 \pm 1.15$ & & 10 & 100 & 303540 & $35 \pm 2.88$ & $<0.01^{*}$ \\
\hline 15 & 100 & 546258 & $58 \pm 2.31$ & $<0.01^{*}$ & 15 & 100 & 81012 & $10 \pm 1.15$ & $<0.01^{*}$ \\
\hline 20 & 100 & 425247 & $47 \pm 2.88$ & $<0.01^{*}$ & 20 & 100 & $-\quad--$ & - & \\
\hline 25 & 100 & 263028 & $28 \pm 1.15$ & $<0.01^{*}$ & 25 & 100 & $-\quad-\quad-$ & - & \\
\hline 30 & 100 & 182412 & $18 \pm 3.46$ & $<0.01^{*}$ & 30 & 100 & $-\quad-\quad-$ & - & \\
\hline
\end{tabular}

*The mean difference is significant at 0.01 level.

days for Sunset Yellow (Table 2(b)), and 45.20 \pm 1.81 $15.14 \pm 0.96$ days for Amaranth (Table 2(c)) in the male applications groups.

As a result of Tartrazine, maximum mean life span belonging to the lowest and highest concentrations (2.5-15 $\left.\mathrm{mg} \mathrm{mL}^{-1}\right)$ was 39-70 days in the female application groups (Table 2(d)) and 39-74 days in the male application groups (Table 2(d)). Additionally, it was determined that mean life span for 우우 is $47.39 \pm 1.84$ $17.40 \pm 1.01$ days and for $0^{7} o^{7}$ is $46.20 \pm 1.87$ $15.97 \pm 1.05$ days.

\section{Discussion}

In our study, the internal and external factors that could affect longevity (maternal age, food type, photoperiod, etc.) were kept constant. Therefore, we can state that the deviations in the longevity of the same genotype and the same-age flies are caused by the effects of different food dyes.

The genotoxic effects of Tartrazine, which was one of the food dyes, on Drosophila were examined using the Somatic Mutation and Recombination Test (SMART), and it was observed that it stimulated recombinogencity [14]. In another study carried out by Tripathy et al. [15], the effects of Rhodamine and Amaranth on D. melanogaster were examined, showing that Rhodamine is genotoxic for both the somatic and reproduction cells, although Amaranth has no such effect. In a study carried out by Macioszek and Kononowicz [16], it has been stated that Black PN and Quinoline Yellow are mutagenic and clastogenic for both lymphocyte cells of humans and Vicia faba stem meristem cells. Also, in another study conducted by Sasaki et al. [17], the genotoxicity of food dyes, such as Amaranth, was investigated at this time, and it was observed that DNA damage occurred on the colon, bladder, stomach, and gastrointestinal organs even at the lowest dose. Mpountoukas et al. [18] investigated the potential genotoxic, cytotoxic and cytostatic in human peripheral blood cells for Amaranth in vitro. According to the results, it was identified that food dyes have a toxic effect on human lymphocyte cells, increase the Sister Chromatid Exchange (SCE) 1.7 times as to control group, and show effect of binding on DNA directly. Similar results were found in a study that was carried out by Shimada et al. [19]. DNA damage was done in rat colon after applying $10 \mathrm{mg}$ $\mathrm{kg}^{-1}$ of azo food dyes. It appeared that the DNA damage was induced on pregnant female and male rats fed with Amaranth orally [20].

In another study performed by Stevenson et al. [21] to identify the hyperactivity causes in children, based on the dyes, it was found that food dyes in- 
Table 2. The longevity of male and female populations of D. melanogaster and the probability levels between groups.

\begin{tabular}{|c|c|c|c|c|c|c|c|c|c|}
\hline \multirow[b]{2}{*}{$\begin{array}{c}\text { Experiment } \\
\text { groups }\end{array}$} & \multirow[b]{2}{*}{$N$} & \multicolumn{4}{|c|}{ Female population } & \multicolumn{4}{|c|}{ Male population } \\
\hline & & $\begin{array}{c}\text { Max.life } \\
\text { span }\end{array}$ & $\begin{array}{c}\text { Mean life } \\
\text { span } \pm \text { SE }\end{array}$ & $\begin{array}{l}\text { Std. } \\
\text { dev. }\end{array}$ & $p$ & $\begin{array}{c}\text { Max. life } \\
\text { span }\end{array}$ & $\begin{array}{c}\text { Mean life } \\
\text { span } \pm \mathrm{SE}\end{array}$ & $\begin{array}{l}\text { Std. } \\
\text { dev. }\end{array}$ & $p$ \\
\hline \multicolumn{10}{|c|}{ (a) Ponceau 4R } \\
\hline Control & 100 & 98 & $66.42 \pm 1.89$ & 18.98 & \multirow{7}{*}{$\begin{array}{l}3-4^{*} \\
4-5^{*} \\
6-7^{*}\end{array}$} & 91 & $62.04 \pm 1.65$ & 16.46 & \multirow[b]{2}{*}{$3-4^{*}$} \\
\hline $5 \mathrm{mg} \mathrm{mL}^{-1}$ & 100 & 87 & $58.43 \pm 1.95$ & 19.52 & & 74 & $42.76 \pm 1.91$ & 19.11 & \\
\hline $10 \mathrm{mg} \mathrm{mL}^{-1}$ & 100 & 74 & $50.43 \pm 1.87$ & 18.68 & & 67 & $35.91 \pm 1.71$ & 17.05 & $3-5^{*}$ \\
\hline $15 \mathrm{mg} \mathrm{mL}^{-1}$ & 100 & 67 & $44.09 \pm 1.77$ & 17.77 & & 63 & $33.48 \pm 1.52$ & 15.22 & $4-5^{*}$ \\
\hline $20 \mathrm{mg} \mathrm{mL}^{-1}$ & 100 & 67 & $40 \pm 1.83$ & 18.33 & & 60 & $30.26 \pm 1.48$ & 14.76 & $4-6^{*}$ \\
\hline $25 \mathrm{mg} \mathrm{mL}^{-1}$ & 100 & 60 & $33 \pm 1.72$ & 17.22 & & 56 & $28.66 \pm 1.35$ & 13.51 & $5-6^{*}$ \\
\hline $30 \mathrm{mg} \mathrm{mL}^{-1}$ & 100 & 53 & $28 \pm 1.48$ & 14.79 & & 42 & $21.66 \pm 1.06$ & 10.55 & \\
\hline \multicolumn{10}{|c|}{ (b) Sunset Yellow } \\
\hline Control & 100 & 98 & $66.42 \pm 1.89$ & 18.98 & \multirow{7}{*}{$\begin{array}{l}4-5^{*} \\
5-6^{*} \\
6-7^{*}\end{array}$} & 91 & $62.04 \pm 1.65$ & 16.45 & \multirow{7}{*}{$\begin{array}{l}4-5^{*} \\
4-6^{*} \\
5-6^{*}\end{array}$} \\
\hline $5 \mathrm{mg} \mathrm{mL}^{-1}$ & 100 & 74 & $51.69 \pm 1.79$ & 17.91 & & 77 & $46.91 \pm 1.93$ & 19.31 & \\
\hline $10 \mathrm{mg} \mathrm{mL}^{-1}$ & 100 & 74 & $45.27 \pm 1.99$ & 19.90 & & 74 & $38.23 \pm 1.68$ & 16.80 & \\
\hline $15 \mathrm{mg} \mathrm{mL}^{-1}$ & 100 & 60 & $38.07 \pm 1.75$ & 17.49 & & 63 & $31.02 \pm 1.78$ & 17.83 & \\
\hline $20 \mathrm{mg} \mathrm{mL}^{-1}$ & 100 & 60 & $33.61 \pm 1.69$ & 16.91 & & 56 & $25.86 \pm 1.43$ & 14.32 & \\
\hline $25 \mathrm{mg} \mathrm{mL}^{-1}$ & 100 & 53 & $29.48 \pm 1.48$ & 14.75 & & 56 & $26.08 \pm 1.49$ & 14.90 & \\
\hline $30 \mathrm{mg} \mathrm{mL}^{-1}$ & 100 & 46 & $24.01 \pm 1.41$ & 14.06 & & 42 & $19.12 \pm 1.27$ & 12.72 & \\
\hline \multicolumn{10}{|c|}{ (c) Amaranth } \\
\hline Control & 100 & 98 & $66.42 \pm 1.89$ & 18.98 & & 91 & $62.04 \pm 1.65$ & 16.45 & \multirow{7}{*}{$\begin{array}{l}4-5^{*} \\
5-6^{*}\end{array}$} \\
\hline $5 \mathrm{mg} \mathrm{mL}^{-1}$ & 100 & 74 & $50.41 \pm 1.97$ & 19.67 & & 67 & $45.20 \pm 1.81$ & 18.09 & \\
\hline $10 \mathrm{mg} \mathrm{mL}^{-1}$ & 100 & 67 & $43.10 \pm 1.72$ & 17.24 & $3-4^{*}$ & 56 & $35.62 \pm 1.61$ & 16.07 & \\
\hline $15 \mathrm{mg} \mathrm{mL}^{-1}$ & 100 & 60 & $39.51 \pm 1.55$ & 15.47 & $4-5^{*}$ & 53 & $27.68 \pm 1.46$ & 14.61 & \\
\hline $20 \mathrm{mg} \mathrm{mL}^{-1}$ & 100 & 60 & $34.92 \pm 1.59$ & 15.94 & $5-6^{*}$ & 46 & $23.82 \pm 1.31$ & 13.11 & \\
\hline $25 \mathrm{mg} \mathrm{mL}^{-1}$ & 100 & 53 & $30.69 \pm 1.39$ & 13.98 & & 46 & $21.09 \pm 1.27$ & 12.68 & \\
\hline $30 \mathrm{mg} \mathrm{mL}^{-1}$ & 100 & 39 & $22.50 \pm 1.17$ & 11.65 & & 35 & $15.14 \pm 0.96$ & 9.61 & \\
\hline \multicolumn{10}{|c|}{ (d) Tartrazine } \\
\hline Control & 100 & 98 & $66.42 \pm 1.89$ & 18.98 & \multirow{7}{*}{$\begin{array}{l}2-3^{*} \\
3-4^{*}\end{array}$} & 91 & $62.04 \pm 1.65$ & 16.45 & \multirow{7}{*}{$\begin{array}{l}2-3^{*} \\
3-4^{*} \\
4-5^{*}\end{array}$} \\
\hline $2.5 \mathrm{mg} \mathrm{mL}^{-1}$ & 100 & 70 & $47.39 \pm 1.84$ & 18.40 & & 74 & $46.20 \pm 1.87$ & 18.72 & \\
\hline $5 \mathrm{mg} \mathrm{mL}^{-1}$ & 100 & 63 & $42.24 \pm 1.64$ & 16.37 & & 63 & $41.08 \pm 1.75$ & 17.49 & \\
\hline $7.5 \mathrm{mg} \mathrm{mL}^{-1}$ & 100 & 60 & $39.28 \pm 1.59$ & 15.93 & & 63 & $38.52 \pm 1.73$ & 17.32 & \\
\hline $10 \mathrm{mg} \mathrm{mL}^{-1}$ & 100 & 53 & $32.48 \pm 1.42$ & 14.16 & & 56 & $33.55 \pm 1.76$ & 17.60 & \\
\hline $12.5 \mathrm{mg} \mathrm{mL}^{-1}$ & 100 & 46 & $24.02 \pm 1.13$ & 11.33 & & 42 & $23.06 \pm 1.16$ & 11.55 & \\
\hline $15 \mathrm{mg} \mathrm{mL}^{-1}$ & 100 & 39 & $17.40 \pm 1.01$ & 10.08 & & 39 & $15.97 \pm 1.05$ & 10.51 & \\
\hline
\end{tabular}

$N$ : Total number of individuals; Max.: Maximum; SE: Standard error;

$p$ : Probability levels between groups; *: The mean difference is not significant at 0.01 level.

hibit the histamine-N-methyltransferase enzyme, and so the histamine that passed to brain and its increased amount increased the hyperactivity. In another study, the amounts of GSH (gamma glutamyl-cyteineylglycine) and MDA (malondialdehit) produced by lipid peroxidation, antioxidant enzyme activity (CAt, GPx), and oxidative stress parameters were identified in the CHO (Chinese Hamster Ovary) cells into which the Tartrazine and New Coccin were applied. To discover the toxic dose of food dyes, the Calcein AM cell viability testing technique was used, and it was identified that tartrazine and new coccin decrease cell viability. It was observed that GSHs in-cell level was greatly reduced; on the contrary, the level of MDA significantly increased in $\mathrm{CHO}$ cells that were exposed to Tartrazine [22].

In the literature search that we carried out, no publication was found regarding the effects of food azo 
dyes on longevity. Therefore, we cannot compare the results of our longevity experiments with any results of literature reviews directly. However, we can state that food azo dyes have mutagenic and clastogenic effects (chromozomal aberrations) on various living beings, and that it can cause a longevity decline. Since usage of high-dose food azo dye can cause serious health threats to humans, we believe that both manufacturing companies and consumers should be informed about food additives.

\section{Conclusion}

In this study, the effects of four different azo dyes used in food industry on the mortality and longevity of the Oregon $\mathrm{R}$ wild larvae of $D$. melanogaster were examined. To this end, results of the different concentrations of the selected food dyes were compared with those of the control group. As a result of our study, a decrease in the number of maturing larvae was observed in comparison with the control group. In addition, it was determined that high doses of food dyes shorten the longevity of $D$. melanogaster. Based on the results obtained by the larval mortality and life span experiments, the order of toxicity for food dyes was Tartrazine $>$ Amaranth $>$ SunsetYellow $\geq$ Ponceau 4R.

\section{References}

1. Sowbhagya, H.B., Smitha, S., Sampathu, S.R., Krishnamurthy, N. and Bhattacharya, S. "Stability of watersoluble turmeric colorant in an extruded food product during storage", J. of Food Eng., 67(3), pp. 367-371 (2005).

2. Yamjala, K., Meyyanathan, S.N. and Nageswara, R.R. "Methods for the analysis of azo dyes employed in food industry -a review", Food Chem., 192, pp. 813-824 (2016).

3. Stingley, R.L., Zou, W., Heinze, T.M., Chen, H. and Cerniglia, C.E. "Metabolism of azo dyes by human skin microbiota", J. of Med. Microbiol, 59(1), pp. 108-114 (2010).

4. de Campos Ventura-Camargo, B. and Marin-Morales, M.A. "Azo dyes: characterization and toxicity -a review", TLIST, 2(2), pp. 85-103 (2013).

5. Ahlström, L.H., Eskilsson, C.S. and Björklund, E. "Determination of banned azo dyes in consumer goods", TrAC Trends Anal. Chem., 24(1), pp. 49-56 (2005).

6. Tsuboy, M.S., Angeli, J.P.F., Mantovani, M.S., Knasmüller, S., Umbuzeiro, G.A. and Ribeiro, L.R. "Genotoxic, mutagenic and cytotoxic effects of the commercial dye CI Disperse Blue 291 in the human hepatic cell line HepG2", Toxicol. Vitro, 21(8), pp. 1650-1655 (2007).
7. Ventura-Camargo, B.C., Maltempi, P.P.P. and MarinMorales, M.A. "The use of the cytogenetic to identify mechanisms of action of an azo dye in Allium Cepa meristematic cells", J. Environ. Anal. Toxicol, 1(3), pp. 1-12 (2011).

8. Amin, K.A, Hameid, H.A. and Elsttar, A.A. "Effect of food azo dyes tartrazine and carmoisine on biochemical parameters related to renal, hepatic function and oxidative stress biomarkers in young male rats", Food. Chem. Toxicol, 48(10), pp. 2994-2999 (2010).

9. Chung, K.T. "Azo dyes and human health: A review", J. Environ. Sci. Health C, 34(4), pp. 233-261 (2016).

10. Bautista, A.R.P.L., Moreira, E.L.T., Batista, M.S., Miranda, M.S. and Gomes, I.C.S. "Subacute toxicity assessment of annatto in rat", Food Chem. Toxicol, 42(4), pp. 625-629 (2004).

11. Poul, M., Jarrya, G., Elhkim, M.O. and Poul, J.M. "Lack of genotoxic effect of food dyes amaranth, sunset yellow and tartrazine and their metabolites in the gut micronucleus assay in mice", Food Chem. Toxicol, 47(2), pp. 443-448 (2009).

12. Han, S. and Yang, Y. "Antimicrobial activity of wool fabric treated with curcumin", Dyes Pigments, 64(2), pp. 157-161 (2005).

13. Poul, M., Jarrya, G., Elhkim, M.O. and Poul, J.M. "Lack of genotoxic effect of food dyes amaranth, sunset yellow and tartrazine and their metabolites in the gut micronucleus assay in mice", Food Chem. Toxicol, 47(2), pp. 443-448 (2009).

14. Niraj, K.T., Kalyani, K.P. and Nabi, M.J. "Genotoxicity of tartrazine studied in two somatic assays of Drosophila melanogaster", Mutat. Res., 224(4), pp. 479-483 (1989).

15. Tripathy, N.K., Nabi, M.J., Sahu, G.P., Kumar, A.A. "Genotoxicity testing of two red dyes in the somatic and germ line cells of Drosophila", Food Chem. Toxicol, 33(11), pp. 923-927 (1995).

16. Macioszek, V.K. and Kononowicz, A.K. "The evaluation of the genotoxicity of two commonly used food colors: Quinoline yellow (E 104) and brilliant black BN (E 151)", Cell Mol. Biol. Lett, 9(1), pp. 107-122 (2004).

17. Sasaki, Y.F., Kawaguchi, S., Kamaya, A., Ohshita, M., Kabasawa, K., Iwama, K., Tanuguchi, K. and Tsuda, S. "The comet assay with 8 mouse organs result with 39 currently used food additives", Mutat. Res., $\mathbf{5 1 9}$ (12), pp. 103-119 (2002).

18. Mpountoukas, P., Pantazaki, A., Kostareli, E., Christodoulou, P., Kareli, D., Poliliou, S., Mourelatos, C., Lambropoulou, V. and Lialiaris, T. "Cytogenetic evaluation and DNA interaction studies of the food colorants amaranth, erythrosine and tartrazine", Food Chem. Toxicol, 48(10) pp. 2934-2944 (2010). 
19. Shimada, C., Kano, K., Sasaki, Y.F., Sato, I. and Tsudua, S. "Differential colon DNA damage induced by azo food additives between rats and mice", $J$ Toxicol. Sci., 35(4), pp. 547-554 (2010).

20. Tsuda, S., Murakami, M., Matsusaka, N., Kano, K. Taniguchi, K. and Sasaki, Y.F. "DNA damage induced by red food dyes orally administered to pregnant and male mice", J Toxicol. Sci., 61(1), pp. 92-99 (2001).

21. Stevenson, J., Sonuga-Barke, E., McCann, D., Grimshaw, K, Parker, K.M., Rose-Zerilli, M.J., Holloway, J.W. and Warner, J.O. "The role of histamine degradation polymorphism in moderating the effects of food additives on children's ADHD symptoms", Am. J. Psychiatry, 167(9), pp. 1108-1115 (2010).

22. Demirkol, O., Zhang, X. and Ercal, N. "Oxidative effects of tartrazine (CAS No. 1934-21-0) and new coccin (CAS No. 2611-82-7) azo dyes on CHO cells", J. Verbr. Lebensm, 7(3), pp. 229-236 (2012).

\section{Biographies}

Handan Uysal is a Professor at the Department of Biology, Faculty of Science, Atatürk University, Erzurum, Turkey. Her research interests include developmental biology, molecular biology, and genetics.

Sidika Genç is a Research Assistant at the Department of Biology, Faculty of Science, Atatürk University, Erzurum, Turkey. Her research interests include biotechnology, molecular biology, and biochemistry.

Arif Ayar is an Assistance Professor Dr. in Sabuncuoğlu Şerefeddin Health Services Vocational School, Amasya University, Amasya, Turkey. His research interests include developmental biology, molecular biology, genetics, genetic toxicology, and Drosophila melanogaster. 